\title{
Prognostic factors for progression of osteoarthritis of the hip: a systematic review
}

\author{
C. H. Teirlinck ${ }^{1 *}$ D, D. M. J. Dorleijn ${ }^{1}$, P. K. Bos², J. B. M. Rijkels-Otters', S. M. A. Bierma-Zeinstra ${ }^{1,2}$ and \\ P. A. J. Luijsterburg ${ }^{1}$
}

\begin{abstract}
Background: Predicting which patients with hip osteoarthritis are more likely to show disease progression is important for healthcare professionals. Therefore, the aim of this review was to assess which factors are predictive of progression in patients with hip osteoarthritis.

Methods: A literature search was made up until 14 March 2019. Included were cohort and case-control studies evaluating the association between factors and progression (either clinical, radiological, or THR). Excluded were studies with a follow-up $<1$ year or specific underlying pathologies of osteoarthritis. Risk of bias was assessed using the QUIPS tool. A best-evidence synthesis was conducted.

Results: We included 57 articles describing 154 different factors. Of these, a best-evidence synthesis was possible for 103 factors, separately for clinical and radiological progression, and progression to total hip replacement. We found strong evidence for more clinical progression in patients with comorbidity and more progression to total hip replacement for a higher Kellgren and Lawrence grade, superior or (supero) lateral femoral head migration, and subchondral sclerosis. Strong evidence for no association was found regarding clinical progression for gender, social support, pain medication, quality of life, and limited range of motion of internal rotation or external rotation. Also, strong evidence for no association was found regarding radiological progression for the markers CTX-I, COMP, NTX-I, PINP, and PIIINP and regarding progression to total hip replacement for body mass index.
\end{abstract}

Conclusion: Strong evidence suggested that 4 factors were predictive of progression of hip osteoarthritis, whereas 12 factors were not predictive of progression. Evidence for most of the reported factors was either limited or conflicting.

Protocol registration: PROSPERO, CRD42015010757

Keywords: Osteoarthritis, Hip, Prognostic factors, Progression, Systematic review

\section{Background}

The hip is the third joint most commonly affected by osteoarthritis (OA) [1]. No therapeutic cure exists for hip OA. Therefore, predicting which patients with hip $\mathrm{OA}$ are more likely to progress in their disease is of special interest, particularly if these predictive factors are potentially modifiable.

In 2002, Lievense et al. published a systematic review in which they identified several predictive factors

\footnotetext{
*Correspondence: c.teirlinck@erasmusmc.nl

'Department of General Practice, Erasmus MC University Medical Center, P.O. Box 2040, 3000 CA Rotterdam, the Netherlands

Full list of author information is available at the end of the article
}

for the progression of hip OA [2]. They used a bestevidence synthesis to draw conclusions about the available evidence per factor. Strong evidence was found for more rapid progression in patients with a superior or superolateral migration of the femoral head or an atrophic bone response. Conversely, strong evidence was found for no association between progression of hip OA and obesity. In 2009, Wright et al. also reviewed the known prognostic factors and their quality of evidence [3]. They concluded that only a few factors are strongly associated with the progression of hip OA, i.e., age, joint space width, migration of the femoral head, femoral osteophytes, 
bony sclerosis, Kellgren and Lawrence (K-L) grade 3, hip pain at baseline, and a Lequesne index score $>10$. In that review, acetabular osteophytes showed no association with progression. Furthermore, de Rooij et al. studied the factors predicting the course of pain and function. They found strong evidence that higher comorbidity count and lower vitality predict a worsening of physical function [4]. Although all reviews described additional predictive factors, the evidence for these factors was either limited or conflicting.

Since the literature search of Wright et al. (in October 2008) and de Rooij et al. (in July 2015) more research on prognostic factors of hip OA have been conducted, and new methods to assess and review prognostic studies have been developed [5].

Therefore, the aim of this present study was to systematically review the evidence of patient, health, and diagnostic variables associated with the progression of hip OA.

\section{Methods}

\section{Search of the literature}

A search was made in the databases of Embase, MEDLINE (OvidSP), Web-of-Science, Cochrane Library, PubMed publisher, and Google Scholar from the inception of the database until 14 March 2019, using the keywords hip, osteoarthritis, and prognosis (and their synonyms). We excluded congress abstracts and editorial letters from our search by setting these as limits to restrain the number of found citations without losing valuable citations. The reference lists of relevant articles were screened for additional relevant studies. A complete syntax of the search can be found in Additional file 1. The process of the search

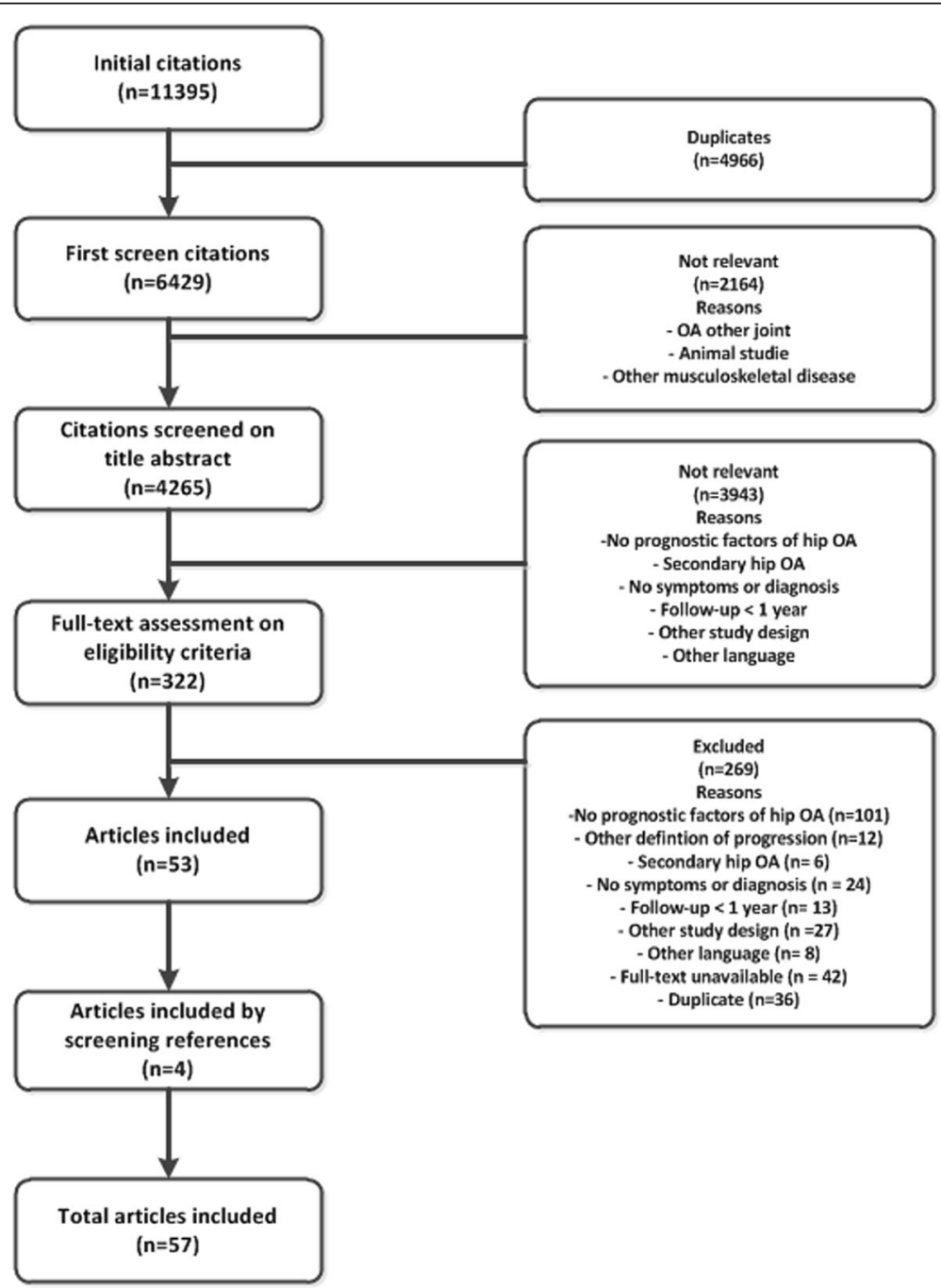

Fig. 1 Flowchart of the search and selection of studies 
Table 1 Characteristics of the selected studies

\begin{tabular}{|c|c|c|c|c|}
\hline Study & Design & $\begin{array}{l}\text { Participants in the } \\
\text { cohort }(n)\end{array}$ & Assessment of progression & $\begin{array}{l}\text { Follow- } \\
\text { up } \\
\text { period }\end{array}$ \\
\hline $\begin{array}{l}\text { Agricola et al. } \\
\text { [11] }\end{array}$ & $\begin{array}{l}\text { Prospective cohort } \\
\text { (CHECK) }\end{array}$ & $\begin{array}{l}1002 \text { (analyzed } \\
723 \text { patients) }\end{array}$ & THR & 5 years \\
\hline $\begin{array}{l}\text { Agricola et al. } \\
{[12]}\end{array}$ & $\begin{array}{l}\text { Prospective cohort } \\
\text { (CHECK) }\end{array}$ & $\begin{array}{l}1002 \text { (analyzed } \\
550 \text { women) }\end{array}$ & THR due to OA & 5 years \\
\hline $\begin{array}{l}\text { Agricola et al. } \\
{[12]}\end{array}$ & $\begin{array}{l}\text { Nested case-control } \\
\text { (Chingford cohort) }\end{array}$ & $\begin{array}{l}1003 \text { (analyzed } \\
114 \text { ) }\end{array}$ & THR due to OA & 19 years \\
\hline $\begin{array}{l}\text { Auquier et al. } \\
{[13]}\end{array}$ & Retrospective cohort & 131 & $\begin{array}{l}\text { Increase in stage of pain and function, stages minimal, moderate, moderate- } \\
\text { severe, severe }\end{array}$ & $\begin{array}{l}6-23 \\
\text { years }\end{array}$ \\
\hline Barr et al. [14] & Case-control & $\begin{array}{l}195 \text { (analyzed } 102 \\
\text { patients) }\end{array}$ & THR (compared to non-progression hips: increase of $\leq 1 \mathrm{~K}-\mathrm{L}$ grade) & 5 years \\
\hline $\begin{array}{l}\text { Bastick et al. } \\
{[15]}\end{array}$ & $\begin{array}{l}\text { Prospective cohort } \\
\text { (CHECK) }\end{array}$ & $\begin{array}{l}545 \text { (analyzed } 363 \\
\text { patients) }\end{array}$ & $\begin{array}{l}\text { NRS score for pain, group moderate progression compared to mild pain. } \\
\text { Groups based on LCGA }\end{array}$ & 5 years \\
\hline $\begin{array}{l}\text { Bastick et al. } \\
{[16]}\end{array}$ & $\begin{array}{l}\text { Prospective cohort } \\
\text { (CHECK) }\end{array}$ & 588 (analyzed 538) & THR & 5 years \\
\hline $\begin{array}{l}\text { Bergink et al. } \\
{[17]}\end{array}$ & $\begin{array}{l}\text { Prospective cohort } \\
\text { (Rotterdam I) }\end{array}$ & 176 & $\begin{array}{l}\text { 1. Increase } \geq 1 \mathrm{~K}-\mathrm{L} \text { grade } \\
\text { 2. Decrease } \geq 1 \mathrm{~mm} \text { of joint space }\end{array}$ & $\begin{array}{l}\text { Average } \\
8.4 \text { years }\end{array}$ \\
\hline Birn et al. [18] & Case-control & $\begin{array}{l}94 \text { ( } 5 \text { cases, } 89 \\
\text { controls) }\end{array}$ & Rapidly destructive OA: $>2 \mathrm{~mm}$ or $>50 \%$ JSN/year & NR \\
\hline Birrell et al. [19] & Prospective cohort & 195 & Time to being put on a waiting list for THR & $\begin{array}{l}36 \\
\text { months }\end{array}$ \\
\hline $\begin{array}{l}\text { Bouyer et al. } \\
\text { [20] }\end{array}$ & $\begin{array}{l}\text { Prospective cohort } \\
\text { (KHOALA) }\end{array}$ & $\begin{array}{l}242 \text { (analyzed } 133 \\
\text { patients) }\end{array}$ & $\begin{array}{l}\text { 1. Increase } \geq 1 \mathrm{~K}-\mathrm{L} \text { grade } \\
\text { 2. Increase } \geq 1 \mathrm{JSN} \text { score } \\
\text { 3. Time to THR }\end{array}$ & 3 years \\
\hline $\begin{array}{l}\text { Castano } \\
\text { Betancourt et } \\
\text { al. [21] }\end{array}$ & $\begin{array}{l}\text { Prospective cohort } \\
\text { (GOAL) }\end{array}$ & 189 & JSN $\geq 20 \%$ compared to baseline or THR & 2 years \\
\hline $\begin{array}{l}\text { Chaganti et al. } \\
\text { [22] }\end{array}$ & $\begin{array}{l}\text { Nested case-control } \\
\text { (SOF) }\end{array}$ & $\begin{array}{l}168 \text { cases and } 173 \\
\text { controls }\end{array}$ & $\begin{array}{l}\text { Decrease in MJS of } 0.5 \mathrm{~mm} \text {, increase of } \geq 1 \text { in summary grade, increase } \geq 2 \text { in } \\
\text { total osteophyte score, or THR for OA }\end{array}$ & $\begin{array}{l}\text { Average } \\
8.3 \text { years }\end{array}$ \\
\hline $\begin{array}{l}\text { Chevalier et al. } \\
\text { [23] }\end{array}$ & Prospective cohort & 30 & Rapid evolution: JSN >0.6 mm/year & 1 year \\
\hline $\begin{array}{l}\text { Conrozier et al. } \\
{[24]}\end{array}$ & Case-control & $\begin{array}{l}104 \text { (analyzed } 10 \\
\text { cases, } 23 \text { controls) }\end{array}$ & $\begin{array}{l}\text { Rapidly progressive hip OA: severe hip pain, symptom onset within the last } 2 \\
\text { years, annual rate of JSN }>1 \mathrm{~mm} \text {, ESR }<20 \mathrm{~mm} / \mathrm{h} \text {, absence of detectable } \\
\text { inflammatory or crystal-induced joint disease }\end{array}$ & NR \\
\hline $\begin{array}{l}\text { Conrozier et al. } \\
{[25]}\end{array}$ & Retrospective cohort & 89 & Radiographic: YMN, calculated from MJS in mm/year & $\begin{array}{l}18-300 \\
\text { months }\end{array}$ \\
\hline $\begin{array}{l}\text { Conrozier et al. } \\
\text { [26] }\end{array}$ & Prospective cohort & 48 & JSN in mm/year & 1 year \\
\hline $\begin{array}{l}\text { Danielsson }[27, \\
\text { 28] }\end{array}$ & Prospective cohort & 168 & $\begin{array}{l}\text { 1. Increase in pain index } 0-5 \\
\text { 2. Operation because of hip } \mathrm{OA} \\
\text { 3. Increase in radiographic index } 0-10\end{array}$ & $\begin{array}{l}8-12 \\
\text { years }\end{array}$ \\
\hline $\begin{array}{l}\text { van Dijk et al. } \\
{[29]}\end{array}$ & Prospective cohort & 123 & $\begin{array}{l}\text { 1. Decrease in WOMAC function } \\
\text { 2. Increase in seconds of timed walking test }\end{array}$ & 3 years \\
\hline $\begin{array}{l}\text { van Dijk et al. } \\
{[30]}\end{array}$ & Prospective cohort & 123 & $\begin{array}{l}\text { 1. Decrease in WOMAC function } \\
\text { 2. Increase in seconds of timed walking test }\end{array}$ & 3 years \\
\hline $\begin{array}{l}\text { Dorleijn et al. } \\
\text { [31] }\end{array}$ & $\begin{array}{l}\text { Prospective cohort } \\
\text { (GOAL) }\end{array}$ & $\begin{array}{l}222 \text { (analyzed } 111 \\
\text { patients) }\end{array}$ & $\begin{array}{l}\text { VAS score for pain, group highly progressive compared to mild pain groups } \\
\text { based on LCGA }\end{array}$ & 2 years \\
\hline $\begin{array}{l}\text { Dougados et } \\
\text { al. [32] }\end{array}$ & $\begin{array}{l}\text { Prospective cohort } \\
\text { (ECHODIAH) }\end{array}$ & $\begin{array}{l}508 \text { (analyzed } 461 \\
\text { patients) }\end{array}$ & Radiological: $\geq 0.6 \mathrm{~mm}$ decrease in JSW & 1 year \\
\hline $\begin{array}{l}\text { Dougados et } \\
\text { al. [33] }\end{array}$ & $\begin{array}{l}\text { Prospective cohort } \\
\text { (ECHODIAH) }\end{array}$ & $\begin{array}{l}508 \text { (analyzed } 463 \\
\text { patients) }\end{array}$ & Radiological: > $0.5 \mathrm{~mm}$ decrease in JSW & 2 years \\
\hline $\begin{array}{l}\text { Dougados et } \\
\text { al. [34] }\end{array}$ & Prospective cohort & 508 & Time to the requirement of THR & 3 years \\
\hline Fukushima et & Prospective cohort & 20 & Increase in Tönnis grade & 25 \\
\hline
\end{tabular}


Table 1 Characteristics of the selected studies (Continued)

\begin{tabular}{|c|c|c|c|c|}
\hline Study & Design & $\begin{array}{l}\text { Participants in the } \\
\text { cohort }(n)\end{array}$ & Assessment of progression & $\begin{array}{l}\text { Follow- } \\
\text { up } \\
\text { period }\end{array}$ \\
\hline al. [35] & & & & months \\
\hline $\begin{array}{l}\text { Golightly et al. } \\
\text { [36] }\end{array}$ & $\begin{array}{l}\text { Prospective cohort } \\
\text { (Johnston County) }\end{array}$ & 1453 & Increase in K-L grade or increase in hip symptoms (mild, moderate, severe) & $\begin{array}{l}3-13 \\
\text { years }\end{array}$ \\
\hline $\begin{array}{l}\text { Gossec et al. } \\
{[37]}\end{array}$ & Prospective cohort & $\begin{array}{l}741 \text { (analyzed } 505 \\
\text { patients) }\end{array}$ & THR & 2 years \\
\hline $\begin{array}{l}\text { Hartofilakidis et } \\
\text { al. [38] }\end{array}$ & Retrospective cohort & 210 & THR & $\begin{array}{l}2 \text { to }> \\
10 \text { years }\end{array}$ \\
\hline $\begin{array}{l}\text { Hawker et al. } \\
\text { [39] }\end{array}$ & Prospective cohort & 2128 & Time to THR & 6.1 years \\
\hline $\begin{array}{l}\text { Hoeven et al. } \\
{[40]}\end{array}$ & $\begin{array}{l}\text { Prospective cohort } \\
\text { (Rotterdam I) }\end{array}$ & $\begin{array}{l}5650 \text { (number } \\
\text { analyzed: NR) }\end{array}$ & Increase $\geq 1 \mathrm{~K}$-L grade baseline to follow-up & 10 years \\
\hline Holla et al. [41] & $\begin{array}{l}\text { Prospective cohort } \\
\text { (CHECK) }\end{array}$ & 588 & $\begin{array}{l}\text { Moving into a higher group (quintiles of WOMAC-PF 0-68) or remaining } \\
\text { within the three highest groups }\end{array}$ & 2 years \\
\hline $\begin{array}{l}\text { Juhakoski et al. } \\
\text { [42] }\end{array}$ & Prospective cohort & 118 & $\begin{array}{l}\text { 1. WOMAC pain }(0-100) \\
\text { 2. WOMAC function }(0-100)\end{array}$ & 2 years \\
\hline $\begin{array}{l}\text { Kalyoncu et al. } \\
\text { [43] }\end{array}$ & $\begin{array}{l}\text { Retrolective cohort } \\
\text { (ECHODIAH) }\end{array}$ & 192 & THR & 10 years \\
\hline $\begin{array}{l}\text { Kelman et al. } \\
{[44]}\end{array}$ & $\begin{array}{l}\text { Nested case-control } \\
\text { (SOF) }\end{array}$ & $\begin{array}{l}396 \text { (cases 197, } \\
\text { controls 199) }\end{array}$ & $\begin{array}{l}\text { Decrease in minimum joint space of } \geq 0.5 \mathrm{~mm} \text {, an increase of } \geq 1 \text { in the } \\
\text { summary grade, an increase of } \geq 2 \text { in total osteophyte score, or THR }\end{array}$ & 8.3 years \\
\hline $\begin{array}{l}\text { Kerkhof et al. } \\
{[45]}\end{array}$ & $\begin{array}{l}\text { Prospective cohort } \\
\text { (Rotterdam I) }\end{array}$ & 1610 & Radiologic: JSN $\leq 1.0 \mathrm{~mm}$ or THR during follow-up & NR \\
\hline $\begin{array}{l}\text { Kopec et al. } \\
{[46]}\end{array}$ & $\begin{array}{l}\text { Prospective cohort } \\
\text { (Johnston County) }\end{array}$ & $\begin{array}{l}1590 \text { (analyzed } \\
571 \text { people) }\end{array}$ & Increase $\geq 1$ in $\mathrm{K}-\mathrm{L}$ grade & $\begin{array}{l}3-13 \\
\text { years }\end{array}$ \\
\hline Lane et al. [47] & $\begin{array}{l}\text { Prospective cohort } \\
\text { (SOF) }\end{array}$ & 745 & $\begin{array}{l}\text { Decrease in minimum joint space of } \geq 0.5 \mathrm{~mm} \text {, an increase of } \geq 1 \text { in the } \\
\text { summary grade, an increase of } \geq 2 \text { in total osteophyte score, or THR }\end{array}$ & 8 years \\
\hline Lane et al. [48] & $\begin{array}{l}\text { Nested case-control } \\
\text { (SOF) }\end{array}$ & 342 & $\begin{array}{l}\text { Radiological: decrease in minimum joint space of } \geq 0.5 \mathrm{~mm} \text {, an increase of } \geq 1 \\
\text { in the summary grade, an increase of } \geq 2 \text { in total osteophyte score, or THR }\end{array}$ & 8.3 years \\
\hline $\begin{array}{l}\text { Laslett et al. } \\
{[49]}\end{array}$ & $\begin{array}{l}\text { Prospective cohort } \\
\text { (TasOAC) }\end{array}$ & $\begin{array}{l}1099 \text { (analyzed } \\
765 \text { people) }\end{array}$ & WOMAC pain $(0-100)$ & $\begin{array}{l}2-4 \\
\text { years }\end{array}$ \\
\hline $\begin{array}{l}\text { Ledingham } \\
1993[50]\end{array}$ & Prospective cohort & 136 & $\begin{array}{l}\text { 1. Global assessment of radiographic change } \\
\text { 2. THR }\end{array}$ & $\begin{array}{l}3-73 \\
\text { months }\end{array}$ \\
\hline $\begin{array}{l}\text { Lievense et al. } \\
\text { [51] }\end{array}$ & Prospective cohort & $\begin{array}{l}224 \text { (analyzed } 163 \\
\text { patients) }\end{array}$ & THR & 5.8 years \\
\hline $\begin{array}{l}\text { Maillefert et al. } \\
\text { [52] }\end{array}$ & $\begin{array}{l}\text { Prospective cohort } \\
\text { (ECHODIAH) }\end{array}$ & 508 & $\begin{array}{l}\text { 1. Decrease in JSW }>50 \% \text { during the first year follow-up } \\
\text { 2. THR in } 1-5 \text { years of follow-up }\end{array}$ & 5 years \\
\hline $\begin{array}{l}\text { Mazieres et al. } \\
{[53]}\end{array}$ & $\begin{array}{l}\text { Prospective cohort } \\
\text { (ECHODIAH) }\end{array}$ & $\begin{array}{l}507 \text { (analyzed } 333 \\
\text { patients) }\end{array}$ & $\mathrm{JSN} \geq 0.5 \mathrm{~mm}$ or THP & 3 years \\
\hline $\begin{array}{l}\text { Nelson et al. } \\
{[54]}\end{array}$ & $\begin{array}{l}\text { Prospective cohort } \\
\text { (Johnston County) }\end{array}$ & 309 & $\begin{array}{l}\text { 1. Increase in } \mathrm{K}-\mathrm{L} \text { grade } \\
\text { 2. Increase in osteophyte severity grade } \\
\text { 3. Increase in JSN severity grade }\end{array}$ & 5 years \\
\hline Perry et al. [55] & Case-control & 44 & Radiographic: progressive deterioration & $\begin{array}{l}5-14 \\
\text { years }\end{array}$ \\
\hline $\begin{array}{l}\text { Peters et al. } \\
{[56]}\end{array}$ & Prospective cohort & $\begin{array}{l}587 \text { (analyzed } 214 \\
\text { patients) }\end{array}$ & New Zealand score $0-80$ (combination of pain and function) & 7 years \\
\hline $\begin{array}{l}\text { Pisters et al. } \\
\text { [57] }\end{array}$ & Prospective cohort & 149 & $\begin{array}{l}\text { Increase in WOMAC function on average over time (measured at 1, 2, 3, } 5 \\
\text { years) }\end{array}$ & 5 years \\
\hline $\begin{array}{l}\text { Pollard 201et } \\
\text { al. } 2[58]\end{array}$ & Prospective cohort & 264 & $\begin{array}{l}\text { Signs on examination of hip OA or symptoms at baseline and signs and } \\
\text { symptoms at follow-up }\end{array}$ & 5 years \\
\hline $\begin{array}{l}\text { Reijman et al. } \\
\text { [59] }\end{array}$ & $\begin{array}{l}\text { Prospective cohort } \\
\text { (Rotterdam I) }\end{array}$ & 1235 & $\mathrm{JSN} \geq 1.0 \mathrm{~mm}$ in at least 1 of 3 compartments (lateral, superior, axial) & 6.6 years \\
\hline Reijman et al. & Prospective cohort & 1904 & Radiologic: JSN $\leq 1.0 \mathrm{~mm}$ or THR during follow-up & 6.6 years \\
\hline
\end{tabular}


Table 1 Characteristics of the selected studies (Continued)

\begin{tabular}{|c|c|c|c|c|}
\hline Study & Design & $\begin{array}{l}\text { Participants in the } \\
\text { cohort }(n)\end{array}$ & Assessment of progression & $\begin{array}{l}\text { Follow- } \\
\text { up } \\
\text { period }\end{array}$ \\
\hline $\begin{array}{l}\text { Reijman et al. } \\
\text { [61] }\end{array}$ & $\begin{array}{l}\text { Prospective cohort } \\
\text { (Rotterdam I) }\end{array}$ & 1676 & $\begin{array}{l}\text { 1. JSN of } \geq 1 \mathrm{~mm} \\
\text { 2. JSN of } \geq 1.5 \mathrm{~mm} \\
\text { 3. Increase of } \geq 1 \mathrm{~K} \text {-L grade }\end{array}$ & 6.6 years \\
\hline Solignac [62] & $\begin{array}{l}\text { Prospective cohort } \\
\text { (ECHODIAH) }\end{array}$ & $\begin{array}{l}507 \text { (analyzed } 333 \\
\text { patients) }\end{array}$ & $\mathrm{JSN} \geq 0.5 \mathrm{~mm}$ or THP & 3 years \\
\hline $\begin{array}{l}\text { van Spil et al. } \\
{[63]}\end{array}$ & $\begin{array}{l}\text { Prospective cohort } \\
\text { (CHECK) }\end{array}$ & $\begin{array}{l}1002 \text { (analyzed } \\
178 \text { patients) }\end{array}$ & Radiographic: $\geq 1 \mathrm{~K}-\mathrm{L}$ grade increase & 5 years \\
\hline $\begin{array}{l}\text { Thompson et } \\
\text { al. [64] }\end{array}$ & Case-control & $\begin{array}{l}34 \text { cases, controls: } \\
\text { NR }\end{array}$ & $\begin{array}{l}\text { Rapidly progressive OA: loss of bone or a combined loss of bone and articular } \\
\text { cartilage at rate }>5 \mathrm{~mm} \text { per year }\end{array}$ & $\begin{array}{l}18 \\
\text { months }\end{array}$ \\
\hline Tron et al. [65] & Retrospective cohort & 39 & Mean annual JSN in mm & NR \\
\hline $\begin{array}{l}\text { Verkleij et al. } \\
\text { [66] }\end{array}$ & $\begin{array}{l}\text { Prospective cohort } \\
\text { (GOAL) }\end{array}$ & $\begin{array}{l}222 \text { (analyzed } 111 \\
\text { patients) }\end{array}$ & $\begin{array}{l}\text { VAS score for pain, group highly progressive compared to mild pain, groups } \\
\text { based on LCGA }\end{array}$ & 2 years \\
\hline $\begin{array}{l}\text { Vinciguerra et } \\
\text { al. [67] }\end{array}$ & Retrospective cohort & 149 & Time to THR & Variable \\
\hline
\end{tabular}

NR not reported, OA osteoarthritis THR total hip replacement, $K$-L grade Kellgren and Lawrence grade, MJS minimum joint space, JSN joint space narrowing, JSW joint space width, YMN yearly mean narrowing, LCGA latent class growth analysis, ESR erythrocyte sedimentation rate, NRS numeric rating scale, VAS visual analog scale

was assisted and partly conducted by an experienced medical librarian.

\section{Criteria for selection of studies}

The following are the criteria for the selection of studies:

1) The study should investigate the factors associated with the progression of hip OA.

2) The article was written in English, Dutch, German, French, Spanish, Italian, Danish, Norwegian, or Swedish. These languages were sufficiently mastered by at least two reviewers.

3) The article was available in full text.

4) Patients in the study reported complaints like pain, disability, or stiffness of the hip, suspected or confirmed (radiographic or clinical criteria) to originate from OA of the hip.

5) The study design was a cohort or a case-control study or a randomized controlled trial in which the estimation of the prognostic factor was adjusted for the intervention or only investigated in the control group.

6) Progression was determined radiographically or clinically. Radiographic progression could be determined by, for example, X-ray or MRI. Examples of clinical progression were worsening of pain or function or reaching the point of indication for total hip replacement (THR).

7) Follow-up should be at least 1 year (based on the recommendations for measuring structural progression [6]).

8) The study was excluded if the population under investigation had a specific underlying pathology, such as trauma (fractures), infection, rheumatoid arthritis, ankylosing spondylitis, Perthes' disease, tuberculosis, hemochromatosis, sickle cell disease, Cushing's syndrome, and femoral head necrosis.

\section{Selection of studies}

CHT screened all the titles and abstracts and excluded articles that did not investigate patients with OA of the hip. Secondly, CHT and PAJL independently selected the titles and abstracts using the selection criteria to decide which articles required the retrieval of full text; in case of disagreement, the full text was retrieved. Then, all full texts were independently assessed by $\mathrm{CHT}$ and PAJL to include all relevant studies according to the selection criteria. In case of disagreement and both reviewers were unable to reach consensus, SMABZ made the final decision.

\section{Data extraction}

Information on the design, setting, study population (e.g., recruitment period, age, gender, definition of hip $\mathrm{OA})$, number of participants, follow-up period, loss to follow-up, prognostic factors, assessment of progression, outcomes, and strength of association were extracted using standardized forms by $\mathrm{CHT}$ and checked by PAJL.

Prognostic factors were divided into patient variables, disease characteristics, and chemical or imaging markers. Outcomes were divided into clinical progression, radiographic progression, or (indication for) receiving a THR.

If outcomes were measured at several follow-up moments, all moments were extracted. After the collection of all data, the follow-up moments that were 
Table 2 Risk of bias assessment summary (QUIPS)

\begin{tabular}{|c|c|c|c|c|c|c|}
\hline Study & $\begin{array}{l}\text { Study } \\
\text { participation }\end{array}$ & $\begin{array}{l}\text { Study } \\
\text { attrition }\end{array}$ & $\begin{array}{l}\text { Prognostic factor } \\
\text { measurement }\end{array}$ & $\begin{array}{l}\text { Outcome } \\
\text { measurement }\end{array}$ & $\begin{array}{l}\text { Study } \\
\text { confounding }\end{array}$ & $\begin{array}{l}\text { Statistical analysis and } \\
\text { reporting }\end{array}$ \\
\hline Agricola et al. [11] & Low & Low & Moderate & Low & Low & Low \\
\hline Agricola et al. [12] & Low & Low & Moderate & Low & Moderate & Low \\
\hline Auquier et al. [13] & Moderate & Moderate & Low & Moderate & High & Moderate \\
\hline Bastick et al. [15] & Low & Low & Low & Low & Low & Low \\
\hline Bastick et al. [16] & Low & Low & Low & Low & Low & Low \\
\hline Bergink et al. [17] & Low & Moderate & Moderate & Low & Low & Moderate \\
\hline Bouyer et al. [20] & Low & High & Moderate & Moderate & Low & Low \\
\hline Birrell et al. [19] & Low & Low & Moderate & Low & Low & Low \\
\hline $\begin{array}{l}\text { Castano Betancourt et } \\
\text { al. [21] }\end{array}$ & Low & Low & Low & Low & Low & Low \\
\hline Chaganti et al. [22] & Low & Low & Low & Low & Moderate & Low \\
\hline Chevalier et al. [23] & Moderate & Low & Low & Low & Moderate & Moderate \\
\hline Conrozier et al. [25] & Moderate & Low & Low & Low & Low & Low \\
\hline Conrozier et al. [26] & Moderate & Low & Low & Low & Low & Low \\
\hline Danielsson $[27,28]$ & Low & High & High & High & High & High \\
\hline van Dijk et al. [29] & Low & Low & Low & Low & Low & Low \\
\hline van Dijk et al. [30] & Low & Low & Low & Low & Low & Low \\
\hline Dorleijn 2015 [31] & Low & Low & Moderate & Low & Moderate & Low \\
\hline Dougados et al. [32] & Low & Low & Low & Low & Low & Low \\
\hline Dougados et al. [33] & Low & Low & Low & Moderate & High & Moderate \\
\hline Dougados et al. [34] & Low & Low & Low & Low & Low & Low \\
\hline Fukushima et al. [35] & Moderate & Low & Low & High & High & Low \\
\hline Golightly et al. [36] & Low & Moderate & Low & Low & Low & Low \\
\hline Gossec et al. [37] & Low & Low & Low & Low & Low & Low \\
\hline Hartofilakidis et al. [38] & Moderate & Moderate & Moderate & Moderate & High & High \\
\hline Hawker et al. [39] & Moderate & Low & Low & Low & Low & Low \\
\hline Hoeven et a. [40] & Low & Moderate & Low & Low & Low & Low \\
\hline Holla et al. [41] & Low & Low & Low & Low & Low & Low \\
\hline Juhakoski et al. [42] & Low & Low & Low & Moderate & Low & Low \\
\hline Kalyoncu et al. [43] & Low & Low & Moderate & Moderate & Low & Low \\
\hline Kelman et al. [44] & Low & Low & Low & Low & Low & Low \\
\hline Kerkhof et al. [45] & Low & Moderate & Moderate & Low & Low & Low \\
\hline Kopec et al. [46] & Low & Moderate & Low & Low & Low & Low \\
\hline Lane et al. [47] & Low & Low & Low & Low & Low & Low \\
\hline Lane et al. [48] & Moderate & Low & Moderate & Low & Low & Low \\
\hline Laslett et al. [49] & Low & Low & Low & Low & Low & Low \\
\hline Ledingham et al. [50] & Moderate & Moderate & Moderate & High & High & High \\
\hline Lievense et al. [51] & Low & Low & Moderate & Low & Low & Low \\
\hline Maillefert et al. [52] & Low & Low & Low & Moderate & Moderate & Moderate \\
\hline Mazieres et al. [53] & Low & Low & Low & Low & Low & Low \\
\hline Nelson et al. [54] & Low & Moderate & Low & Low & Low & Low \\
\hline Peters et al. [56] & Low & Moderate & Moderate & Low & Moderate & Low \\
\hline Pisters et al. [57] & Low & Low & Low & Low & Low & Low \\
\hline Pollard et al. [58] & Low & Low & Low & Moderate & Low & Low \\
\hline
\end{tabular}


Table 2 Risk of bias assessment summary (QUIPS) (Continued)

\begin{tabular}{|c|c|c|c|c|c|c|}
\hline Study & $\begin{array}{l}\text { Study } \\
\text { participation }\end{array}$ & $\begin{array}{l}\text { Study } \\
\text { attrition }\end{array}$ & $\begin{array}{l}\text { Prognostic factor } \\
\text { measurement }\end{array}$ & $\begin{array}{l}\text { Outcome } \\
\text { measurement }\end{array}$ & $\begin{array}{l}\text { Study } \\
\text { confounding }\end{array}$ & $\begin{array}{l}\text { Statistical analysis and } \\
\text { reporting }\end{array}$ \\
\hline Reijman et al. [59] & Low & Moderate & Low & Low & Low & Low \\
\hline Reijman et al. [60] & Low & Moderate & Low & Low & Low & Low \\
\hline Reijman et al. [61] & Low & Moderate & Low & Low & Low & Low \\
\hline Solignac [62] & Low & Low & Low & Low & Moderate & Low \\
\hline van Spil et al. [63] & Low & Low & Low & Low & Low & Low \\
\hline Tron et al. [65] & High & High & High & Moderate & High & Moderate \\
\hline Verkleij et al. [66] & Low & Low & Low & Low & Moderate & Low \\
\hline Vinciguerra et al. [67] & Low & Moderate & High & Low & High & High \\
\hline
\end{tabular}

Studies with a low risk of bias in all domains are presented in italics

in the closest range to each other were used for the evidence synthesis.

\section{Risk of bias assessment}

The quality of all included cohort studies was evaluated using the QUIPS tool [5, 7]. Studies were assessed on six domains: study participation, study attrition, prognostic factor measurement, outcome measurement, study confounding, and statistical analysis and reporting. An overview of all domains and their items is presented in Additional file 2. Each study was independently scored by $\mathrm{CHT}$ and by a second reviewer (DMJD, SMABZ, PKB, JBMRO, or PAJL). In case of disagreement, they attempted to reach consensus; if this failed, a third reviewer (JBMRO or PAJL) made the final decision.

\section{Evidence synthesis}

A meta-analysis was considered if clinical heterogeneity was low, with respect to the study population, the risk of bias, and the definition of prognostic factors and defined hip OA progression. In case of a meta-analysis, an adjusted GRADE assessment for prognostic research was used to determine the strength of the evidence [8].

If the level of heterogeneity of the studies was high, we refrained from pooling in the main analysis and performed a qualitative evidence synthesis. Associations were categorized as positive, negative, or no association. Ranking of the levels of evidence was based on Lievense et al. [2] and Davis et al. [9]:

1) Strong evidence: consistent findings ( $\geq 75 \%$ of the studies showing the same direction of the association) in two or more studies with a low risk of bias in all domains of the QUIPS tool

2) Moderate evidence: consistent findings in more than two studies with a moderate or high risk of bias in one or more domains of the QUIPS tool or consistent findings in two studies, of which one study has a low risk of bias in all domains of the QUIPS tool

3) Limited evidence: one study with a low risk of bias in all domains of the QUIPS tool or two studies with a moderate or high risk of bias in one or more domains of the QUIPS tool

4) Conflicting evidence: $<75 \%$ of the studies showing the same direction of the association

If a prognostic factor was described in two different articles that investigated the same study cohort and outcome of progression, one study was selected to include in the evidence synthesis. In this case, we selected the article according to a decision tree: (1) lowest risk of bias, (2) prognostic factor is the primary outcome of the study, and (3) the largest number of participants.

\section{Post hoc changes to the study protocol}

After contact with one of the developers of the QUIPS tool, we learned that it is not validated to judge the risk of bias of case-control studies and would probably not adequately take into account the higher risk of recall bias and the selection bias of case-control studies. Therefore, we decided to exclude case-control studies from our evidence synthesis, except for nested case-control studies. Nested case-control studies are less prone to selection and recall bias because of the underlying known cohort [10], which can be judged using the QUIPS tool.

\section{Results}

\section{Included studies}

The initial search yielded 6429 citations of which 57 articles were finally included. Figure 1 shows the reasons for the study exclusion, and Table 1 presents a brief overview of the characteristics of the 57 included studies (a 
Table 3 Factors predicting (indication for) total hip replacement (THR)

\begin{tabular}{|c|c|c|}
\hline $\begin{array}{l}\text { Prognostic } \\
\text { factor }\end{array}$ & Studies & Associations \\
\hline \multicolumn{3}{|c|}{ Patient variables } \\
\hline \multicolumn{3}{|c|}{ No association } \\
\hline \multicolumn{3}{|c|}{ Body mass index } \\
\hline & $\begin{array}{l}2 \text { low risk of bias cohorts }[16,37] \\
5 \text { cohorts }[20,39,50,51,67]\end{array}$ & $\begin{array}{l}\text { No, no } \\
\text { No, no, no, negative } \\
\text { positive }\end{array}$ \\
\hline
\end{tabular}

Female

$$
\begin{array}{ll}
3 \text { low risk of bias cohorts [16, 34, } & \text { No, positive, no } \\
37] & \text { No, no, no, no, no } \\
5 \text { cohorts }[20,39,50-52] &
\end{array}
$$

Lower educational level

$$
\begin{array}{ll}
1 \text { low risk of bias cohort [16] } & \text { No } \\
1 \text { cohort [39] } & \text { No }
\end{array}
$$

Western or White ethnicity

1 low risk of bias cohort [16] No

1 cohort [39] No

Alcohol consumption

1 low risk of bias cohort [16]

No

Conflicting evidence

Higher age at baseline

$\begin{array}{ll}3 \text { low risk of bias cohorts [16, 34, } & \begin{array}{l}\text { No, positive, no } \\ \text { 37] }\end{array} \\ 5 \text { cohorts }[20,39,50,51,67] & \text { positive }\end{array}$

Disease characteristics

Faster or more progression

Lower global assessment (self-reported) at baseline

$\begin{array}{ll}1 \text { low risk of bias cohort [37] } & \text { Positive } \\ 2 \text { cohorts }[39,50] & \text { Positive, positive }\end{array}$

Previous use of NSAIDs

1 low risk of bias cohort [37]

No association

Longer duration of symptoms at baseline

$$
1 \text { low risk of bias cohort [37] }
$$$$
1 \text { cohort [19] }
$$

Having another disease (comorbidity)

1 low risk of bias cohort [16] 1 cohort [39]

Morning stiffness

1 low risk of bias cohort [16]

1 cohort [51]

Use of pain medication at baseline

1 low risk of bias cohort [16]

1 cohort [19]

Presence of Heberden's or Bouchard's nodes

1 low risk of bias cohort [16]

2 cohorts $[50,51]$

Previous intra-articular injection in the hip

1 low risk of bias cohort [37]

Positive

No

No

No

No, no
Best-evidence synthesis

Strong evidence for no association

Moderate evidence for no association

Moderate evidence for no association

Moderate evidence for no association

Limited evidence for no association

Conflicting evidence

Moderate evidence for faster or more progression

Limited evidence for more progression

Moderate evidence for no association

Moderate evidence for no association

Moderate evidence for no association

Moderate evidence for no association

Moderate evidence for no association

Limited evidence for no association 
Table 3 Factors predicting (indication for) total hip replacement (THR) (Continued)

\begin{tabular}{|c|c|c|}
\hline $\begin{array}{l}\text { Prognostic } \\
\text { factor }\end{array}$ & Studies & Associations \\
\hline \multicolumn{3}{|c|}{ Conflicting evidence } \\
\hline \multicolumn{3}{|c|}{ More limitations in physical function at baseline } \\
\hline & $\begin{array}{l}3 \text { low risk of bias cohorts }[16,34, \\
37] \\
2 \text { cohorts }[19,39]\end{array}$ & $\begin{array}{l}\text { Positive, positive, no } \\
\text { No, no }\end{array}$ \\
\hline
\end{tabular}

More pain at baseline

$\begin{array}{ll}3 \text { low risk of bias cohorts [16, 34, } & \begin{array}{l}\text { Conflicted }^{\text {\$\$ }} \text {, positive, } \\ \text { positive }\end{array} \\ 4 \text { cohorts }[19,39,50,51] & \text { Positive, no, positive, no }\end{array}$

$\begin{array}{ll}1 \text { low risk of bias cohort [16] } & \text { Positive } \\ 1 \text { cohort [51] } & \text { No }\end{array}$

Painful hip internal rotation (active or passive)

$\begin{array}{ll}1 \text { low risk of bias cohort [16] } & \text { Positive } \\ 1 \text { cohort [51] } & \text { No }\end{array}$

Night pain at baseline

$$
2 \text { cohorts }[50,51]
$$

Limited range of motion of flexion of the hip

$$
\begin{array}{ll}
1 \text { low risk of bias cohort [16] } & \text { Positive } \\
2 \text { cohorts }[19,51] & \text { Positive, no }
\end{array}
$$

Limited range of motion of internal hip rotation

$$
\begin{array}{ll}
1 \text { low risk of bias cohort [16] } & \text { Positive } \\
2 \text { cohorts }[19,51] & \text { Positive, no }
\end{array}
$$

Limited range of motion of external hip rotation

$$
2 \text { cohorts }[19,51] \quad \text { Positive, no }
$$

Chemical or imaging markers

Faster or more progression

Higher K-L grade at baseline

$$
\begin{array}{ll}
2 \text { low risk of bias cohorts [34, 37] } & \text { Positive, positive } \\
1 \text { cohorts [51] } & \text { Positive }
\end{array}
$$

Superior or superolateral migration of the femoral head

$$
\begin{array}{ll}
2 \text { low risk of bias cohorts [34, 47] } & \text { Positive, positive } \\
1 \text { cohort [38] } & \text { Positive }
\end{array}
$$

Subchondral sclerosis

$$
2 \text { low risk of bias cohorts }[16,47] \text { Positive, positive }
$$

Statistical shape modeling

$$
3 \text { cohorts }[11,12,12]
$$

Positive, positive, positive

Joint space narrowing at baseline

$$
\begin{array}{ll}
1 \text { low risk of bias cohort [16] } & \text { Positive } \\
1 \text { cohort [67] } & \text { Positive }
\end{array}
$$

No association

Cam-type deformity (alpha angle $>60^{\circ}$ )

$$
1 \text { low risk of bias cohort [16] }
$$

No

Conflicting evidence

Erythrocyte sedimentation rate

$$
\begin{array}{ll}
1 \text { low risk of bias cohort [16] } & \text { Positive } \\
1 \text { cohort [51] } & \text { No }
\end{array}
$$

Atrophic bone response (no osteophytes present)
Conflicting evidence

Conflicting evidence

\section{Best-evidence synthesis}

$$
\text { Conficting evidence }
$$

Conflicting evidence

Conflicting evidence

Conflicting evidence

Conflicting evidence

Conflicting evidence

Conflicting evidence

Strong evidence for more or faster progression

Strong evidence for more or faster progression

Strong evidence for more progression

Moderate evidence that certain modes of SSM can predict progression

Moderate evidence for more or faster progression

Limited evidence for no association

Conflicting evidence

Conflicting evidence 
Table 3 Factors predicting (indication for) total hip replacement (THR) (Continued)

\begin{tabular}{|c|c|c|c|}
\hline \multirow[t]{2}{*}{$\begin{array}{l}\text { Prognostic } \\
\text { factor }\end{array}$} & Studies & Associations & Best-evidence synthesis \\
\hline & $\begin{array}{l}1 \text { low risk of bias cohort [16] } \\
2 \text { cohorts }[50,51]\end{array}$ & $\begin{array}{l}\text { Positive } \\
\text { Positive, no }\end{array}$ & \\
\hline \multicolumn{3}{|c|}{ Decrease in joint space width at baseline } & Conflicting evidence \\
\hline & $\begin{array}{l}1 \text { low risk of bias cohort [34] } \\
1 \text { cohort [51] }\end{array}$ & $\begin{array}{l}\text { Positive } \\
\text { No }\end{array}$ & \\
\hline \multicolumn{3}{|c|}{ Wiberg's center edge angle (CEA) } & Conflicting evidence \\
\hline & $\begin{array}{l}1 \text { low risk of bias cohort [16] } \\
1 \text { cohort [20] }\end{array}$ & $\begin{array}{l}\text { Negative } \\
\text { No }\end{array}$ & \\
\hline
\end{tabular}

\footnotetext{
\$Exception: age $\geq 82$ years showed a negative association with progression, compared to age $\leq 62$ years

\$Pain at baseline measured with NRS past week showed a statistically significant positive association with THR; pain at baseline measured with WOMAC pain showed no statistically significant association with THR
}

more extensive overview is available in Additional file 3). Of the 57 studies, 48 were cohort studies (37 with a prospective design), 4 were nested case-control studies, and 5 were case-control studies. These last 5 studies were excluded from the evidence synthesis for the reasons mentioned above.

\section{Risk of bias assessment}

In $68 \%$ of all assessed domains from all studies, there was an immediate consensus between the reviewers (Cohen's kappa 0.375, linear weighted kappa 0.484). In 9 assessments of a domain (3\%) in 6 different studies, a third reviewer made the final judgment. In total, 15 studies scored a low risk of bias in all domains $[15,16,21,29,30,32,34,37,41,44,47,49$, 53, 57, 63] (Table 2).

\section{Prognostic factors}

We identified 154 possible prognostic factors: 23 patient variables, 77 disease characteristics, and 54 chemical markers or imaging markers. Fifty-one factors were only investigated once in a single cohort or study (not a low risk of bias study) and could not be included in the evidence synthesis. An overview of all the results and risk of bias assessment of the studies describing these factors is presented in Additional file 4. The remaining 103 factors were included in the evidence synthesis. To decrease heterogeneity, evidence synthesis was done separately per group of outcomes (radiological progression, clinical progression, or THR). However, heterogeneity was still considered high in each outcome group, mainly within respect to the definition of the prognostic factor, progression, and measure of the association. Therefore, we refrained from pooling and performed a best-evidence synthesis. If a factor could not be subdivided because it was described by two or three studies that used a definition of progression, all in a separate group of outcome, we combined the groups of outcomes. The results of these factors are presented in Additional file 5.

\section{Evidence for factors predicting progression}

Strong evidence was found for a higher K-L grade at baseline, superior or (supero) lateral femoral head migration, and subchondral sclerosis to be predictive of faster progression to THR or more patients progressing to THR. Body mass index was found not to be predictive of faster or more progression to THR (Table 3).

Strong evidence was found for no association between radiological progression and the following markers: C-terminal telopeptide of collagen type I (CTX-I), cartilage oligomeric matrix protein (COMP), $\mathrm{N}$-terminal telopeptide of collagen type I (NTX-I), and N-terminal propeptide of procollagen type $\mathrm{I}$ and type III (PINP, PIIINP) (Table 4).

Strong evidence showed comorbidity to be predictive of clinical progression. On the other hand, gender, social support, use of pain medication at baseline, quality of life at baseline, and limited range of motion of internal hip rotation or external hip rotation were not predictive of clinical progression (Table 5).

For other factors, only moderate, limited, or conflicting evidence was found for predicting or not predicting progression (Tables 3, 4, and 5).

\section{Discussion}

In this study, we systematically reviewed all 154 factors predictive of progression of hip OA, reported in 57 studies. Compared to earlier reviews, there was a considerable amount of additional evidence available for the factors previously reported in reviews, as well as evidence for factors not earlier described.

In this review, some results had changed compared to the review of Lievense et al. in 2002 [2]. Firstly, because of the new evidence emerging from the later studies, especially studies with a clinical outcome of progression. Secondly, because we used a different 
Table 4 Factors predicting radiological progression

\begin{tabular}{|c|c|c|c|}
\hline Prognostic factor & Studies & Associations & Best-evidence synthesis \\
\hline \multicolumn{4}{|l|}{ Patient variables } \\
\hline \multicolumn{4}{|l|}{ No association } \\
\hline \multicolumn{3}{|c|}{ Family history of OA } & \multirow[t]{2}{*}{ Moderate evidence for no association } \\
\hline & 3 cohorts $[25,60,65]$ & No, no, no & \\
\hline \multicolumn{3}{|c|}{ Body mass index } & \multirow[t]{2}{*}{ Moderate evidence for no association } \\
\hline & 4 cohorts $[25,50,61,65]$ & No, no, no, no & \\
\hline \multicolumn{4}{|c|}{ Conflicting evidence } \\
\hline \multicolumn{3}{|c|}{ Higher age at baseline or at first symptoms } & \multirow[t]{2}{*}{ Conflicting evidence } \\
\hline & $\begin{array}{l}1 \text { low risk of bias cohort [32] } \\
4 \text { cohorts }[35,50,60,65]\end{array}$ & $\begin{array}{l}\text { Positive } \\
\text { No, positive, positive, no }\end{array}$ & \\
\hline \multicolumn{3}{|l|}{ Female } & \multirow[t]{2}{*}{ Conflicting evidence } \\
\hline & $\begin{array}{l}1 \text { low risk of bias cohort [32] } \\
6 \text { cohorts }[25,27,35,50,60,65]\end{array}$ & $\begin{array}{l}\text { Positive } \\
\text { No, no, no, no, positive, no }\end{array}$ & \\
\hline \multicolumn{4}{|c|}{ Disease characteristics } \\
\hline \multicolumn{4}{|c|}{ Faster or more progression } \\
\hline \multicolumn{3}{|c|}{ More limitations in physical function at baseline } & \multirow[t]{2}{*}{ Moderate evidence for more progressio } \\
\hline & $\begin{array}{l}1 \text { low risk of bias cohort [32] } \\
1 \text { cohort [60] }\end{array}$ & $\begin{array}{l}\text { Positive } \\
\text { Positive }\end{array}$ & \\
\hline \multicolumn{3}{|c|}{ Hip pain present at baseline or on most days for a least 1 month in the past year } & \multirow[t]{2}{*}{ Moderate evidence for more progressio } \\
\hline & $\begin{array}{l}1 \text { low risk of bias cohort [47] } \\
1 \text { cohort [60] }\end{array}$ & $\begin{array}{l}\text { Positive } \\
\text { Positive }\end{array}$ & \\
\hline \multicolumn{4}{|l|}{ No association } \\
\hline \multirow[t]{2}{*}{ Forestier's dis } & & & \multirow[t]{2}{*}{ Moderate evidence for no association } \\
\hline & 3 cohorts $[25,50,65]$ & No, no, no & \\
\hline \multicolumn{2}{|c|}{ Diabetes mellitus } & & \multirow[t]{2}{*}{ Limited evidence for no association } \\
\hline & 2 cohorts $[25,60]$ & No, no & \\
\hline \multicolumn{2}{|c|}{ Bilateral hip OA } & & \multirow[t]{2}{*}{ Limited evidence for no association } \\
\hline & 2 cohorts $[25,65]$ & No, no & \\
\hline \multicolumn{2}{|c|}{ Generalized OA } & & \multirow[t]{2}{*}{ Limited evidence for no association } \\
\hline & 2 cohorts $[25,65]$ & No, no & \\
\hline
\end{tabular}

Chemical or imaging markers

Faster or more progression

subchondral sclerosis

1 low risk of bias cohort [47]
1 cohort [33]

Neck width of the femoral head

1 low risk of bias cohort [21]

Osteocalcin (OC)

1 low risk of bias cohort [63]

No association

C-terminal telopeptide of collagen type I (CTX-I)

2 low risk of bias cohorts $[53,63]$

Cartilage oligomeric matrix protein (COMP)

3 low risk of bias cohorts $[44,53,63]$

1 cohort [26]

N-terminal telopeptide of collagen type I (NTX-I)
Moderate evidence for more progression

Positive

Positive

Limited evidence for more progression

Positive

Negative

Limited evidence for less progression

Strong evidence for no association

No, no

Strong evidence for no association

No, no, no

Positive

Strong evidence for no association 
Table 4 Factors predicting radiological progression (Continued)

\begin{aligned} & \hline Prognostic factor Studies \\
& \hline N-terminal propeptide of procollagen type I (PINP) 2 low risk of bias cohorts [44, 63] \\
& 2 low risk of bias cohorts [53, 63] \\
& N-terminal propeptide of procollagen type III (PIIINP) 2 low risk of bias cohorts [53, 63] \\
& High-sensitive C-reactive protein (hs-CRP) \\
& 1 low risk of bias cohort [53] \\
& 1 cohort [45] \\
& Angle of the femoral head \\
& 1 low risk of bias cohort [21] \\
& 2 cohorts [20, 65] \\
& Acetabular osteophytes only \\
& 1 low risk of bias cohort [47] \end{aligned}

$\mathrm{N}$-terminal propeptide of procollagen type IIA (PIIANP)

$$
1 \text { low risk of bias cohort [63] }
$$

Chondroitin sulphate 846 (CS846)

1 low risk of bias cohort [63]

Cartilage glycoprotein 40 (YKL-40)

1 low risk of bias cohort [53]

Matrix metalloproteinases (MMP-1)

1 low risk of bias cohort [53]

Matrix metalloproteinases (MMP-3)

1 low risk of bias cohort [53]

Neck length of the femoral head

1 low risk of bias cohort [21]

Conflicting evidence

Bone mineral content

1 low risk of bias cohort [21]

Area/size of the hip joint

1 low risk of bias cohort [21]

C-terminal telopeptide of collagen type II (CTX-II)

2 low risk of bias cohorts $[53,63]$ 1 cohort [59]

Hyaluronic acid (HA)

2 low risk of bias cohorts $[53,63]$ 1 cohort [23]

Atrophic bone response (no osteophytes present)

1 low risk of bias cohort [47]

3 cohorts $[25,50,65]$

Subchondral cysts

1 low risk of bias cohort [47]

1 cohort [33]

Decrease in joint space width at baseline

1 low risk of bias cohort [32]

2 cohorts [25, 60]

Superior or (supero) lateral migration of the femoral head

Associations

No, no

No, no

No, no

No

No

No

No, no

No

No

No

No

No

No

No

No

Conflicted $^{\text {s }}$

Conflicted $^{\$}$

Positive, no

Positive

Positive, no

No

No

Positive, positive, no

Positive

No

Positive

No, positive
Conflicting evidence

Conflicting evidence

Conflicting evidence

Conflicting evidence

Conflicting evidence

Conflicting evidence

Best-evidence synthesis

Strong evidence for no association

Strong evidence for no association

Moderate evidence for no association

Moderate evidence for no association

Moderate evidence for no association

Limited evidence for no association

Limited evidence for no association

Limited evidence for no association

Limited evidence for no association

Limited evidence for no association

Limited evidence for no association

Conflicting evidence

Conflicting evidence 
Table 4 Factors predicting radiological progression (Continued)

\begin{tabular}{|c|c|c|c|}
\hline Prognostic factor & Studies & Associations & Best-evidence synthesis \\
\hline & $\begin{array}{l}2 \text { low risk of bias cohorts }[32,47] \\
2 \text { cohorts }[25,50]\end{array}$ & $\begin{array}{l}\text { Positive, no } \\
\text { No, positive }\end{array}$ & \\
\hline \multicolumn{3}{|c|}{ Higher K-L grade at baseline } & Conflicting evidence \\
\hline & 4 cohorts $[33,50,60,65]$ & No, positive, positive, no & \\
\hline \multicolumn{3}{|c|}{ Acetabular index (Horizontal toit externe angle) } & Conflicting evidence \\
\hline & 2 cohorts $[20,65]$ & Conflicted $^{\$ \$}$, no & \\
\hline \multicolumn{3}{|c|}{ Wiberg's center edge angle (CEA) } & Conflicting evidence \\
\hline & 2 cohorts $[20,65]$ & \multicolumn{2}{|l|}{ No, negative } \\
\hline \multicolumn{4}{|c|}{$\begin{array}{l}\text { \$BMC of superior }(p=0.009) \text { and medial }(p=0.019) \text { quart femoral head, arc regions } 2-4(p=0.02,0.001,0.003 \text {, respectively), and the acetabular arc was higher in } \\
\text { patients with progression than without progression. BMC of the femoral neck }(p=0.17) \text {, intertrochanteric area }(p=0.9) \text {, trochanteric area }(p=0.6) \text {, and inferior }(p= \\
0.08) \text { and lateral }(p=0.06) \text { quart femoral head and arc region } 1(p=0.19) \text { of acetabular arc was not significantly different between patients with or } \\
\text { without progression } \\
\text { \$\$ The area/size of superior }(p=0.002) \text {, medial }(p=0.002) \text {, inferior }(p=0.003) \text {, and lateral }(p=0.003) \text { femoral head and of arc regions } 2-4(p=0.007,0.001 \text { and } 0.005 \\
\text { respectively) of acetabular arc was higher in patients with progression than without progression. The area/size of the femoral neck }(p=0.6) \text {, intertrochanteric area } \\
(p=0.16) \text {, trochanteric area }(p=0.4) \text {, and arc region } 1(p=0.2) \text { of the acetabular arc was not significantly different between patients with progression and } \\
\text { without progression. }\end{array}$} \\
\hline
\end{tabular}

method to assess the risk of bias, some studies were no longer considered to have a low risk of bias. The QUIPS tool seems to apply stricter criteria than the method used by Lievense et al. in 2002. Thirdly, we divided the outcomes into three different groups of progression. Thus, due to these methodological differences (together with additional studies), we were unable to confirm an atrophic bone response as a predictor for radiological progression or progression to THR. On the other, we were able to confirm their conclusion on BMI as not predictive of progression and faster progression in patients with a superolateral migration of the femoral head.

Most of the prognostic factors reported by Wright et al. in 2009 [3] were confirmed in this present review in one or more of the outcome groups. The differences found in age, femoral and acetabular osteophytes, and hip pain at baseline were (as with Lievense et al.) a combination of new evidence, differences in the risk of bias assessment, and the division into defined groups of progression. The study from de Rooij et al. in 2016 [4] reviewed the evidence for predictors of the course of pain and function and found comorbidity and vitality (SF-36) to be predictive of function, as we found for clinical progression. However, although they also used the QUIPS tool to assess the risk of bias, they used a different cutoff point to classify a study as having a low risk of bias. Therefore, some earlier findings of strong evidence for no association with the course of pain or function were confirmed as only moderate evidence for no association with clinical progression in our review. Other differences between this review and the present one are mainly attributable to the differences in the selection criteria. In Table 6, we summarized all factors with strong evidence to be predictive of progression found in one of these four reviews and the overlap and differences in evidence for these factors.

Strengths of this present review are the sensitive literature search and our systematic approach to the selection, risk of bias assessment, and the best-evidence synthesis. Therefore, we have presented an extensive overview of reported prognostic factors and existing evidence for their associations. In performing the evidence synthesis divided into outcome (radiological, clinical, or THR), we decreased the heterogeneity and we believe the results to be more accurate for daily practice. Unfortunately, heterogeneity was still too high to perform a meta-analysis. Therefore, we were bound to a best-evidence synthesis and unable to calculate the strengths of the associations. This limits the translation to the daily clinical practice. Another disadvantage of this synthesis compared to a metaanalysis is that smaller studies contribute to the result with the same weight as larger studies, even though the smaller studies may have low power to show a statistically significant association.

In the selection of studies, several restrictions were imposed. First, languages were restricted to ensure that at least two researchers had a reasonable understanding of the languages included so all articles were reliably assessed. However, this implies that we may have missed studies from countries in which publication in English is less common. Secondly, negative results (i.e., no association was found) are less likely to be published and are therefore not well represented in this review.

We used the QUIPS tool to assess the risk of bias. Nine other studies using this tool reported an interrater agreement ranging from 70 to $89.5 \%$ (median 
Table 5 Factors predicting clinical progression

\begin{tabular}{|c|c|}
\hline Prognostic factor & Studies \\
\hline \multicolumn{2}{|l|}{ Patient variables } \\
\hline \multicolumn{2}{|l|}{ No association } \\
\hline \multicolumn{2}{|l|}{ Female } \\
\hline & $\begin{array}{l}2 \text { low risk of bias cohorts }[41,57] \\
5 \text { cohorts }[13,27,42,56,66]\end{array}$ \\
\hline \multicolumn{2}{|c|}{ Social support } \\
\hline & 2 low risk of bias cohorts $[41,57]$ \\
\hline \multicolumn{2}{|c|}{ Higher age at baseline } \\
\hline & $\begin{array}{l}1 \text { low risk of bias cohort }[41,57] \\
3 \text { cohorts }[42,56,66]\end{array}$ \\
\hline \multicolumn{2}{|c|}{ Paid employment } \\
\hline & $\begin{array}{l}1 \text { low risk of bias cohort [41] } \\
2 \text { cohorts }[42,56]\end{array}$ \\
\hline \multicolumn{2}{|l|}{ Living alone } \\
\hline & $\begin{array}{l}1 \text { low risk of bias cohort [41] } \\
1 \text { cohort [30] }\end{array}$ \\
\hline \multicolumn{2}{|c|}{ Alcohol consumption } \\
\hline & 1 low risk of bias cohort [41] \\
\hline \multicolumn{2}{|c|}{ Conflicting evidence } \\
\hline \multicolumn{2}{|c|}{ Physical activity during leisure } \\
\hline & 1 low risk of bias cohort [41] \\
\hline \multicolumn{2}{|c|}{ Body mass index } \\
\hline & $\begin{array}{l}2 \text { low risk of bias cohorts }[41,57] \\
3 \text { cohorts }[42,56,66]\end{array}$ \\
\hline
\end{tabular}

Lower education level

2 low risk of bias cohorts $[41,57]$

2 cohorts $[42,66]$

Disease characteristics

Faster or more progression

Having another disease (comorbidity)

$$
\begin{aligned}
& 2 \text { low risk of bias cohorts [41, 57] } \\
& 1 \text { cohort [42] }
\end{aligned}
$$

Concurrent morning stiffness of the knee $(<30 \mathrm{~min})$

1 low risk of bias cohort [41]

No association

Use of (pain) medication at baseline

2 low risk of bias cohorts $[29,41]$

Quality of life at baseline

2 low risk of bias cohort [30,41]

Limited range of motion of internal hip rotation

2 low risk of bias cohorts $[41,57]$

1 cohort [66]

Limited range of motion of external hip rotation

2 low risk of bias cohorts $[15,57]$

Concurrent knee pain

1 low risk of bias cohort [41]

1 cohort [66]
Associations

Best-evidence synthesis

Strong evidence for no association

No, no

Positive, no, no, no, no

Strong evidence for no association

No, no

Moderate evidence for no association

No, positive

No, no, no

Moderate evidence for no association

No

No, no

Moderate evidence for no association

No

No

Limited evidence for no association

No

Conflicted $^{\$}$

Conflicting evidence

Conflicting evidence

Positive, no

No, no, positive

Conflicting evidence

No, negative

Positive, no

Strong evidence for more progression

Positive $^{\$ \$}$, positive

Positive

Limited evidence for more progression

Positive

Strong evidence for no association

No, no

Strong evidence for no association

No $\$ \$$, no

Strong evidence for no association

No, no

No

Strong evidence for no association

No, no

Moderate evidence for no association
No

No 
Table 5 Factors predicting clinical progression (Continued)

\begin{tabular}{cll}
\hline Prognostic factor & Studies & A \\
\hline Depression & & \\
& 1 low risk of bias cohort [41] & No \\
& 1 cohort [56] & $N$
\end{tabular}

Way of coping

Associations

No

No

1 low risk of bias cohort [41] No

1 cohort [30] No

Respiratory comorbidity

$$
\begin{aligned}
& 1 \text { low risk of bias cohort [29] } \\
& 1 \text { cohort [56] }
\end{aligned}
$$

No

No

Patient-rated health

$$
1 \text { low risk of bias cohort [41] }
$$

Cardiac comorbidity (cumulative illness rating scale 1, severity score $\geq 2$ )

$$
1 \text { low risk of bias cohort [29] }
$$

Vascular comorbidity (cumulative illness rating scale 2, severity score $\geq 2$ )

$$
1 \text { low risk of bias cohort [29] }
$$

$$
\text { No }
$$

Eye, ear, nose, throat, and larynx diseases (cumulative illness rating scale 4, severity score $\geq 2$ )

1 low risk of bias cohort [29]

No

Upper gastrointestinal comorbidity (cumulative illness rating scale 5, severity score $\geq 2$ )

$$
1 \text { low risk of bias cohort [29] }
$$

$$
\text { No }
$$

Lower gastrointestinal comorbidity (cumulative illness rating scale 6, severity score $\geq 2$ )

$$
1 \text { low risk of bias cohort [29] No }
$$

Hepatic comorbidity (cumulative illness rating scale 7, severity score $\geq 2$ )

$$
1 \text { low risk of bias cohort [29] No }
$$

Renal comorbidity (cumulative illness rating scale 8, severity score $\geq 2$ )

$$
1 \text { low risk of bias cohort [29] No }
$$

Other genitourinary comorbidities (cumulative illness rating scale 9 , severity score $\geq 2$ )

$$
1 \text { low risk of bias cohort [29] No }
$$

Neurological comorbidity (cumulative illness rating scale 11, severity score $\geq 2$ )

$$
1 \text { low risk of bias cohort [29] No }
$$

Psychiatric comorbidity (cumulative illness rating scale 12, severity score $\geq 2$ )

$$
1 \text { low risk of bias cohort [29] No }
$$

Comorbidity of endocrine and metabolic diseases (cumulative illness rating scale 13, severity score $\geq 2$ )

$$
1 \text { low risk of bias cohort [29] No }
$$

Cognitive functioning

$$
1 \text { low risk of bias cohort [57] }
$$

Muscle strength hip abduction

1 low risk of bias cohort [57]

Pain during sitting or lying

$$
1 \text { low risk of bias cohort [41] }
$$

Joint stiffness (WOMAC)

1 low risk of bias cohort [15]

Use of additional supplements or vitamins

1 low risk of bias cohort [15]

Concurrent pain during flexion of ipsilateral knee

1 low risk of bias cohort [15]
No

No

No

No

No

No
Best-evidence synthesis

Moderate evidence for no association

Moderate evidence for no association

Moderate evidence for no association

Limited evidence for no association

Limited evidence for no association

Limited evidence for no association

Limited evidence for no association

Limited evidence for no association

Limited evidence for no association

Limited evidence for no association

Limited evidence for no association

Limited evidence for no association

Limited evidence for no association

Limited evidence for no association

Limited evidence for no association

Limited evidence for no association

Limited evidence for no association

Limited evidence for no association

Limited evidence for no association

Limited evidence for no association

Limited evidence for no association 
Table 5 Factors predicting clinical progression (Continued)

\begin{tabular}{|c|c|c|c|}
\hline Prognostic factor & Studies & Associations & Best-evidence synthesis \\
\hline \multirow[t]{2}{*}{ Knee flexion } & & & Limited evidence for no association \\
\hline & 1 low risk of bias cohort [29] & No & \\
\hline \multirow[t]{2}{*}{ Knee extensio } & & & Limited evidence for no association \\
\hline & 1 low risk of bias cohort [29] & No & \\
\hline \multicolumn{2}{|c|}{ Strength of isometric knee extension } & & Limited evidence for no association \\
\hline & 1 low risk of bias cohort [29] & No & \\
\hline \multicolumn{4}{|c|}{ Conflicting evidence } \\
\hline \multirow[t]{2}{*}{ Bilateral hip } & & & Conflicting evidence \\
\hline & $\begin{array}{l}1 \text { low risk of bias cohort [41] } \\
1 \text { cohort [66] }\end{array}$ & $\begin{array}{l}\text { Positive, if equal symptoms } \\
\text { No }\end{array}$ & \\
\hline \multicolumn{2}{|c|}{ Pain at baseline (self-reported or during physical examination) } & & Conflicting evidence \\
\hline & 3 low risk of bias cohorts $[29,41,47]$ & No, no, positive & \\
\hline \multicolumn{2}{|c|}{ Longer duration of symptoms at baseline } & & Conflicting evidence \\
\hline & $\begin{array}{l}1 \text { low risk of bias cohort [57] } \\
2 \text { cohorts }[42,66]\end{array}$ & $\begin{array}{l}\text { No } \\
\text { No, positive }\end{array}$ & \\
\hline \multicolumn{2}{|c|}{ Morning stiffness } & & Conflicting evidence \\
\hline & $\begin{array}{l}1 \text { low risk of bias cohort [41] } \\
1 \text { cohort [66] }\end{array}$ & $\begin{array}{l}\text { No } \\
\text { Positive }\end{array}$ & \\
\hline \multicolumn{2}{|c|}{ Limited range of motion of flexion of the hip } & & Conflicting evidence \\
\hline & $\begin{array}{l}2 \text { low risk of bias cohorts }[41,57] \\
1 \text { cohort }[66]\end{array}$ & $\begin{array}{l}\text { Positive, no } \\
\text { No }\end{array}$ & \\
\hline \multicolumn{4}{|c|}{ Chemical or imaging markers } \\
\hline \multicolumn{4}{|c|}{ Conflicting evidence } \\
\hline \multicolumn{2}{|c|}{ Higher $\mathrm{K}-\mathrm{L}$ grade at baseline } & & Conflicting evidence \\
\hline & $\begin{array}{l}1 \text { low risk of bias cohort }[12] \\
2 \text { cohorts }[42,66]\end{array}$ & $\begin{array}{l}\text { No } \\
\text { No, positive }\end{array}$ & \\
\hline
\end{tabular}

\footnotetext{
\$Patients who were 3-5 days/week physically active in their leisure time showed less progression than patients who were 0-2 days/week physically active in their leisure time. No difference was found between patients spending 6-7 days/week on physical activity and patients spending $0-2$ days/week on physical activity $\$ \$ 3$ more diseases compared to no comorbidities

${ }^{\$ \$}$ Subscale of SF-36 vitality showed a positive association with WOMAC function score
}

$83.5 \%)$ and a kappa statistic ranging from 0.56 to 0.82 (median 0.75) [7]. Compared to these data, our interrater agreement was low and considered to be moderate. Disagreement was mainly due to the differences in interpretation of items of the QUIPS tool; however, only for very few items, a third reviewer was needed to make a final decision.

Hip dysplasia and femoral acetabular impingement were initially considered to be underlying pathologies and were excluded from this analysis. However, the range of severity of these morphologies is substantial, i.e., some of these morphologies should clearly be considered as an underlying pathology, whereas others are more subtle and sometimes undiagnosed. These subtle morphologies might be considered to be possible prognostic factors, rather than underlying pathologies. Therefore, all citations were screened using the terms "hip dysplasia" and "femoral acetabular impingement" in the title or abstract. However, we found only one small study [35] which investigated the radiographic findings of femoral acetabular impingement as a prognostic factor (results of this study are included in Additional file 4). In the studies already included, three studies did not specifically include patients with hip dysplasia or femoral acetabular impingement but did investigate the associated angles (Wiberg's center edge angle and alpha angle, respectively). Since the evidence for these associations with the progression of hip OA was weak, future studies and reviews should investigate these morphologies as possible prognostic factors.

\section{Conclusion}

We conclude that there is consistent evidence that four factors (comorbidity, K-L grade, superior or (supero) lateral femoral head migration, and subchondral sclerosis) were predictive of progression of hip OA, whereas 12 factors were not predictive. The 
Table 6 Overview of factors with strong evidence to be predictive of progression, overlap and differences between this review and the review of de Rooij et al., Wright et al., and Lievense et al.

\begin{tabular}{|c|c|c|c|c|}
\hline Prognostic factor & Teirlinck et al. factor predictive of & De Rooij et al. factor predictive of & $\begin{array}{l}\text { Wright et al. } \\
\text { factor } \\
\text { predictive of }\end{array}$ & $\begin{array}{l}\text { Lievense et al. } \\
\text { factor } \\
\text { predictive of }\end{array}$ \\
\hline $\begin{array}{l}\text { K-L grade at } \\
\text { baseline }\end{array}$ & THR & $\begin{array}{l}\text { Strong evidence for no association for } \\
\text { clinical progression }\end{array}$ & $\begin{array}{l}\text { Radiological } \\
\text { progression } \\
\text { or } \mathrm{THR}^{*}\end{array}$ & Not mentioned \\
\hline $\begin{array}{l}\text { Subchondral } \\
\text { sclerosis at baseline }\end{array}$ & THR & Not mentioned & $\begin{array}{l}\text { Radiological } \\
\text { progression } \\
\text { and/or THR }\end{array}$ & Not mentioned \\
\hline $\begin{array}{l}\text { Superior or (supero) } \\
\text { lateral femoral head } \\
\text { migration }\end{array}$ & THR & Not mentioned & $\begin{array}{l}\text { Radiological } \\
\text { progression } \\
\text { and/or THR }\end{array}$ & $\begin{array}{l}\text { Radiological } \\
\text { progression } \\
\text { and/or THR }\end{array}$ \\
\hline Comorbidity & Clinical progression & $\begin{array}{l}\text { Clinical progression (strong evidence } \\
\text { for a course of function, weak } \\
\text { evidence for a course of pain) }\end{array}$ & Not mentioned & Not mentioned \\
\hline Low vitality & $\begin{array}{l}\text { Quality of life in general: strong evidence of no } \\
\text { association, specific for SF } 36 \text { vitality: strong } \\
\text { evidence for clinical progression }\end{array}$ & Course of function & Not mentioned & Not mentioned \\
\hline Age & $\begin{array}{l}\text { Conflicted evidence for THR and radiological } \\
\text { progression, moderate evidence for no } \\
\text { association with clinical progression }\end{array}$ & $\begin{array}{l}\text { Strong evidence for no association with } \\
\text { pain and conflicted evidence for function }\end{array}$ & $\begin{array}{l}\text { Radiological } \\
\text { progression } \\
\text { and/or THR }\end{array}$ & $\begin{array}{l}\text { Conflicted } \\
\text { evidence }\end{array}$ \\
\hline $\begin{array}{l}\text { Femoral } \\
\text { osteophytes }\end{array}$ & Conflicted evidence & Not mentioned & $\begin{array}{l}\text { Radiological } \\
\text { progression } \\
\text { and/or THR }\end{array}$ & Not mentioned \\
\hline Hip pain at baseline & Conflicted evidence & Conflicted evidence & $\begin{array}{l}\text { Radiological } \\
\text { progression } \\
\text { and THR }\end{array}$ & Not mentioned \\
\hline JSW at baseline & Conflicted evidence & Not mentioned & $\begin{array}{l}\text { Radiological } \\
\text { progression } \\
\text { and/or THR }\end{array}$ & $\begin{array}{l}\text { Limited } \\
\text { evidence for } \\
\text { THR }\end{array}$ \\
\hline $\begin{array}{l}\text { Lequesne index } \\
\text { score } \geq 10 \text { at } \\
\text { baseline }\end{array}$ & $\begin{array}{l}\text { Conflicted evidence for THR, moderate evidence } \\
\text { for radiological progression** }\end{array}$ & Conflicted evidence ${ }^{* *}$ & $\begin{array}{l}\text { Radiological } \\
\text { progression } \\
\text { and/or THR }\end{array}$ & Not mentioned \\
\hline $\begin{array}{l}\text { Atrophic bone } \\
\text { response }\end{array}$ & Conflicted evidence & Not mentioned & $\begin{array}{l}\text { Conflicted } \\
\text { evidence }\end{array}$ & $\begin{array}{l}\text { Radiological } \\
\text { progression }\end{array}$ \\
\hline
\end{tabular}

${ }^{*} \mathrm{~K}-\mathrm{L}$ grade 3 at baseline

**Function at baseline in general

bold text represents strong evidence to be predictive of progression

evidence for other factors was weak or conflicting. Health professionals caring for patients with hip OA will benefit from the insight in prognostic factors, e.g., patients more likely to progress rapidly may need an intensified symptomatic treatment or early referral to an orthopedic surgeon. For this, we still need more high-quality research focusing on the prognostic factors in hip OA.

\section{Additional files}

Additional file 1: Syntax of literature search. (DOCX $15 \mathrm{~kb}$ )

Additional file 2: Criteria items of QUIPS tool and possible adjustments. (DOCX $42 \mathrm{~kb}$ )

Additional file 3: Characteristics of the selected studies: extensive overview. (DOCX $172 \mathrm{~kb}$ )

Additional file 4: Prognostic factors described by one study or multiple studies from the same cohort. (DOCX $126 \mathrm{~kb}$ )
Additional file 5: Factors predicting total hip replacement, clinical or radiological progression combined. (DOCX $82 \mathrm{~kb}$ )

\section{Abbreviations}

BMI: Body mass index; COMP: Cartilage oligomeric matrix protein; CS846: Chondroitin sulphate 846; CTX-I: C-terminal telopeptide of collagen type I; CTX-III: C-terminal telopeptide of collagen type II; ESR: Erythrocyte sedimentation rate; GRADE: Grading of Recommendations Assessment, Development and Evaluation; HA: Hyaluronic acid; hs-CRP: High-sensitive Creactive protein; JSN: Joint space narrowing; JSW: Joint space width; K-L grade: Kellgren and Lawrence grade; LCGA: Latent class growth analysis; MJS: Minimum joint space; MMP-1: Matrix metalloproteinases-1; MMP3: Matrix metalloproteinases-3; MRI: Magnetic resonance imaging; NRS: Numeric rating scale; NTX-I: N-terminal telopeptide of collagen type l; OA: Osteoarthritis; OC: Osteocalcin; PIIANP: N-terminal propeptide of procollagen type IIA; PIIINP: N-terminal propeptide of procollagen type III; PINP: N-terminal propeptide of procollagen type I; QUIPS: Quality in prognosis studies; THR: Total hip replacement; VAS: Visual analog scale; WOMAC: Western Ontario and McMaster Universities Osteoarthritis Index; YKL-40: Cartilage glycoprotein 40; YMN: Yearly mean narrowing 


\section{Acknowledgements}

The authors thank Wichor Bramer for assisting with the literature search and Nadine Rasenberg and Mohammed Boudjemaoui for assisting with the selection, assessment, and data extraction of the French-language literature.

\section{Authors' contributions}

CHT was responsible for the methods, search, selection, data extraction, assessment, analysis, and drafting the article. DMJD, PKB, and SMABZ were responsible for the methods, assessment, and critical revision of the article. JBMRO was responsible for the assessment and critical revision of the article. PAJL was responsible for the methods, selection, data extraction, assessment, analysis, and extensive revision of the article. All authors read and approved the final manuscript.

\section{Funding}

This research was financially supported by a program grant from the Dutch Arthritis Foundation for their center of excellence "Osteoarthritis in primary care".

\section{Availability of data and materials}

Data sharing is not applicable to this article as no datasets were generated or analyzed during the current study.

\section{Ethics approval and consent to participate}

Not applicable

\section{Consent for publication}

Not applicable

\section{Competing interests}

Dr. Bierma-Zeinstra reports grants from the Netherlands Organisation for Health Research and Development (Health Care Efficiency Research Programme), during the conduct of the study; grants from Dutch Arthritis Foundation, the Netherlands Organisation for Health Research and Development, and EU Horizon 2020, Stichting Coolsingel, Nuts-Ohra, and EU Fp7, other from Regeneron, and Infirst Healthcare; personal fees from Osteoarthritis \& Cartilage; personal fees from OARSI, EULAR, Regeneron, and Infirst Healthcare, outside the submitted work. The other authors certify that he or she has no commercial associations (e.g., consultancies, stock ownership, equity interest, patent/licensing arrangements) that might pose a conflict of interest in connection with the submitted article.

\section{Author details}

'Department of General Practice, Erasmus MC University Medical Center, P.O. Box 2040, 3000 CA Rotterdam, the Netherlands. '2Department of Orthopedics, Erasmus MC University Medical Center, P.O. Box 2040, 3000 CA Rotterdam, the Netherlands.

\section{Published online: 23 August 2019}

\section{References}

1. Litwic A, Edwards MH, Dennison EM, Cooper C. Epidemiology and burden of osteoarthritis. Br Med Bull. 2013;105:185-99.

2. Lievense AM, Bierma-Zeinstra SM, Verhagen AP, Verhaar JA, Koes BW. Prognostic factors of progress of hip osteoarthritis: a systematic review. Arthritis Rheum. 2002;47(5):556-62.

3. Wright AA, Cook C, Abbott JH. Variables associated with the progression of hip osteoarthritis: a systematic review. Arthritis Rheum. 2009;61(7):925-36.

4. de Rooij M, van der Leeden M, Heymans MW, Holla JF, Hakkinen A, Lems WF, Roorda LD, Veenhof C, Sanchez-Ramirez DC, de Vet HC, et al. Course and predictors of pain and physical functioning in patients with hip osteoarthritis: systematic review and meta-analysis. J Rehabil Med. 2016; 48(3):245-52.

5. Hayden JA, Cote P, Bombardier C. Evaluation of the quality of prognosis studies in systematic reviews. Ann Intern Med. 2006;144(6):427-37.

6. Altman RD, Bloch DA, Dougados M, Hochberg M, Lohmander S, Pavelka K Spector T, Vignon E. Measurement of structural progression in osteoarthritis of the hip: the Barcelona consensus group. Osteoarthr Cartilage. 2004;12(7): 515-24.
7. Hayden JA, van der Windt DA, Cartwright $\mathrm{J}$, Cote P, Bombardier C. Assessing bias in studies of prognostic factors. Ann Intern Med. 2013;158(4): 280-6.

8. Huguet A, Hayden JA, Stinson J, McGrath PJ, Chambers CT, Tougas ME, Wozney L. Judging the quality of evidence in reviews of prognostic factor research: adapting the GRADE framework. Syst Rev. 2013;2:71.

9. Davis P, Hayden J, Springer J, Bailey J, Molinari M, Johnson P. Prognostic factors for morbidity and mortality in elderly patients undergoing acute gastrointestinal surgery: a systematic review. Can J Surg. 2014;57(2):E44-52.

10. Ernster VL. Nested case-control studies. Prev Med. 1994;23(5):587-90.

11. Agricola R, Reijman M, Bierma-Zeinstra SMA, Verhaar JAN, Weinans $H$, Waarsing $\mathrm{JH}$. Total hip replacement but not clinical osteoarthritis can be predicted by the shape of the hip: a prospective cohort study (CHECK). Osteoarthr Cartilage. 2013;21(4):559-64.

12. Agricola R, Leyland KM, Bierma-Zeinstra SM, Thomas GE, Emans PJ, Spector TD, Weinans H, Waarsing JH, Arden NK. Validation of statistical shape modelling to predict hip osteoarthritis in females: data from two prospective cohort studies (Cohort Hip and Cohort Knee and Chingford). Rheumatology (Oxford). 2015;54(11):2033-41.

13. Auquier L, Paolaggi JB, Cohen De Lara A. Long term evolution of pain in a series of 273 coxarthrosis. Rev Rhum Mal Osteo-Articul. 1979;46(3): 153-62.

14. Barr RJ, Gregory JS, Reid DM, Aspden RM, Yoshida K, Hosie G, Silman AJ, Alesci S, Macfarlane GJ. Predicting OA progression to total hip replacement: can we do better than risk factors alone using active shape modelling as an imaging biomarker? Rheumatology (Oxford). 2012;51(3):562-70.

15. Bastick AN, Verkleij SPJ, Damen J, Wesseling J, Hilberdink WKHA, Bindels PJE, Bierma-Zeinstra SMA. Defining hip pain trajectories in early symptomatic hip osteoarthritis - 5 year results from a nationwide prospective cohort study (CHECK). Osteoarthr Cartil. 2016:24(5):768-75.

16. Bastick AN, Damen J, Agricola R, Brouwer RW, Bindels PJ, Bierma-Zeinstra SM. Characteristics associated with joint replacement in early symptomatic knee or hip osteoarthritis: 6-year results from a nationwide prospective cohort study (CHECK). Br J Gen Pract. 2017;67(663):e724-31.

17. Bergink AP, Zillikens MC, Van Leeuwen JPTM, Hofman A, Uitterlinden AG, van Meurs JBJ. 25-Hydroxyvitamin D and osteoarthritis: a meta-analysis including new data. Semin Arthritis Rheum. 2016;45(5):539-46.

18. Birn J, Pruente R, Avram R, Eyler W, Mahan M, van Holsbeeck M. Sonographic evaluation of hip joint effusion in osteoarthritis with correlation to radiographic findings. J Clin Ultrasound. 2014;42(4):205-11.

19. Birrell F, Afzal C, Nahit E, Lunt M, Macfarlane GJ, Cooper C, Croft PR, Hosie G, Silman AJ. Predictors of hip joint replacement in new attenders in primary care with hip pain. Br J Gen Pract. 2003;53(486):26-30.

20. Bouyer B, Mazieres B, Guillemin F, Bouttier R, Fautrel B, Morvan J, Pouchot J, Rat AC, Roux $\mathrm{CH}$, Verrouil $\mathrm{E}$, et al. Association between hip morphology and prevalence, clinical severity and progression of hip osteoarthritis over 3 years: the knee and hip osteoarthritis long-term assessment cohort results. Jt Bone Spine. 2016;83(4):432-8.

21. Castano Betancourt MC, Van der Linden JC, Rivadeneira F, Rozendaal RM, Bierma Zeinstra SM, Weinans H, Waarsing JH. Dual energy x-ray absorptiometry analysis contributes to the prediction of hip osteoarthritis progression. Arthritis Res Ther. 2009;11(6):R162.

22. Chaganti RK, Kelman A, Lui L, Yao W, Javaid MK, Bauer D, Nevitt M, Lane NE, for the Study of Osteoporotic Fractures Research G. Change in serum measurements of cartilage oligomeric matrix protein and association with the development and worsening of radiographic hip osteoarthritis. Osteoarthr Cartilage. 2008;16(5):566-71.

23. Chevalier X, Conrozier T, Gehrmann M, Claudepierre P, Mathieu P, Unger S, Vignon E. Tissue inhibitor of metalloprotease-1 (TIMP-1) serum level may predict progression of hip osteoarthritis. Osteoarthr Cartilage. 2001;9(4):300-7.

24. Conrozier T, Chappuis-Cellier C, Richard M, Mathieu P, Richard S, Vignon E. Increased serum C-reactive protein levels by immunonephelometry in patients with rapidly destructive hip osteoarthritis. Rev Rhum Engl Ed. 1998; 65(12):759-65.

25. Conrozier T, Jousseaume CA, Mathieu P, Tron AM, Caton J, Bejui J, Vignon E. Quantitative measurement of joint space narrowing progression in hip osteoarthritis: a longitudinal retrospective study of patients treated by total hip arthroplasty. Br J Rheumatol. 1998;37(9):961-8.

26. Conrozier T, Saxne T, Fan CSS, Mathieu P, Tron AM, Heinegard D, Vignon E. Serum concentrations of cartilage oligomeric matrix protein and bone 
sialoprotein in hip osteoarthritis: a one year prospective study. Ann Rheum Dis. 1998;57(9):527-32.

27. Danielsson LG. Incidence and prognosis of coxarthrosis. Acta Orthop Scand Suppl. 1964;66(SUPPL 66):61-114.

28. Danielsson LG. Incidence and prognosis of coxarthrosis. Clin Orthop Relat Res. 1993;287:13-8.

29. van Dijk GM, Veenhof C, Spreeuwenberg P, Coene N, Burger BJ, van Schaardenburg D, van den Ende CH, Lankhorst GJ, Dekker J. Prognosis of limitations in activities in osteoarthritis of the hip or knee: a 3-year cohort study. Arch Phys Med Rehabil. 2010;91(1):58-66.

30. Van Dijk GM, Veenhof C, Lankhorst GJ, Van Den Ende CH, Dekker J. Vitality and the course of limitations in activities in osteoarthritis of the hip or knee. BMC Musculoskelet Disord. 2011;12:269.

31. Dorleijn DMJ, Luijsterburg PAJ, Bay-Jensen AC, Siebuhr AS, Karsdal MA, Rozendaal RM, Bos PK, Bierma-Zeinstra SMA. Association between biochemical cartilage markers and clinical symptoms in patients with hip osteoarthritis: cohort study with 2-year follow-up. Osteoarthr Cartilage. 2015;23(1):57-62.

32. Dougados $M$, Gueguen A, Nguyen $M$, Berdah L, Lequesne $M$, Mazieres B, Vignon E. Radiological progression of hip osteoarthritis: definition, risk factors and correlations with clinical status. Ann Rheum Dis. 1996;55(6):356-62.

33. Dougados $M$, Gueguen $A$, Nguyen $M$, Berdah L, Lequesne $M$, Mazieres B, Vignon E. Radiographic features predictive of radiographic progression of hip osteoarthritis. Rev Rhum Engl Ed. 1997;64(12):795-803.

34. Dougados M, Gueguen A, Nguyen M, Berdah L, Lequesne M, Mazieres B, Vignon E. Requirement for total hip arthroplasty: an outcome measure of hip osteoarthritis? J Rheumatol. 1999;26(4):855-61.

35. Fukushima K, Inoue G, Uchida K, Fujimaki H, Miyagi M, Nagura N, Uchiyama K, Takahira N, Takaso M. Relationship between synovial inflammatory cytokines and progression of osteoarthritis after hip arthroscopy. Exp Assess. J Orthop Surg. 2018;26(2):1-6.

36. Golightly YM, Allen KD, Helmick CG, Schwartz TA, Renner JB, Jordan JM. Hazard of incident and progressive knee and hip radiographic osteoarthritis and chronic joint symptoms in individuals with and without limb length inequality. J Rheumatol. 2010;37(10):2133-40.

37. Gossec L, Tubach F, Baron G, Ravaud P, Logeart I, Dougados M. Predictive factors of total hip replacement due to primary osteoarthritis: a prospective 2 year study of 505 patients. Ann Rheum Dis. 2005;64(7):1028-32.

38. Hartofilakidis $\mathrm{G}$, Karachalios T. Idiopathic osteoarthritis of the hip: incidence, classification, and natural history of 272 cases. Orthopedics. 2003;26(2):161-6.

39. Hawker GA, Guan J, Croxford R, Coyte PC, Glazier RH, Harvey BJ, Wright JG, Williams JI, Badley EM. A prospective population-based study of the predictors of undergoing total joint arthroplasty. Arthritis Rheum. 2006;54(10):3212-20.

40. Hoeven TA, Kavousi M, Clockaerts S, Kerkhof HJM, Van Meurs JB, Franco O, Hofman A, Bindels P, Witteman J, Bierma-Zeinstra S. Association of atherosclerosis with presence and progression of osteoarthritis: the Rotterdam Study. Ann Rheum Dis. 2013;72(5):646-51.

41. Holla JFM, Steultjens MPM, Roorda LD, Heymans MW, Ten Wolde S, Dekker J. Prognostic factors for the two-year course of activity limitations in early osteoarthritis of the hip and/or knee. Arthritis Care Res. 2010;62(10):1415-25.

42. Juhakoski R, Malmivaara A, Lakka TA, Tenhonen S, Hannila ML, Arokoski JP. Determinants of pain and functioning in hip osteoarthritis - a two-year prospective study. Clin Rehabil. 2013;27(3):281-7.

43. Kalyoncu U, Gossec L, Nguyen M, Berdah L, Mazieres B, Lequesne M, Dougados $M$. Self-reported prevalence of psoriasis and evaluation of the impact on the natural history of hip osteoarthritis: results of a 10 years follow-up study of 507 patients (ECHODIAH study). Jt Bone Spine. 2009;76(4):389-93.

44. Kelman A, Lui L, Yao W, Krumme A, Nevitt M, Lane NE. Association of higher levels of serum cartilage oligomeric matrix protein and $\mathrm{N}$-telopeptide crosslinks with the development of radiographic hip osteoarthritis in elderly women. Arthritis Rheum. 2006;54(1):236-43.

45. Kerkhof HJM, Bierma-Zeinstra SMA, Castano-Betancourt MC, De Maat MP, Hofman A, Pols HAP, Rivadeneira F, Witteman JC, Uitterlinden AG, Van Meurs JBJ. Serum C reactive protein levels and genetic variation in the CRP gene are not associated with the prevalence, incidence or progression of osteoarthritis independent of body mass index. Ann Rheum Dis. 2010; 69(11):1976-82.

46. Kopec JA, Sayre EC, Schwartz TA, Renner JB, Helmick CG, Badley EM, Cibere J, Callahan LF, Jordan JM. Occurrence of radiographic osteoarthritis of the knee and hip among african americans and whites: a population-based prospective cohort study. Arthritis Care Res. 2013; 65(6):928-35.
47. Lane NE, Nevitt MC, Hochberg MC, Hung YY, Palermo L. Progression of radiographic hip osteoarthritis over eight years in a community sample of elderly white women. Arthritis Rheum. 2004;50(5):1477-86.

48. Lane NE, Nevitt MC, Lui LY, De Leon P, Corr M. Wht signaling antagonists are potential prognostic biomarkers for the progression of radiographic hip osteoarthritis in elderly Caucasian women. Arthritis Rheum. 2007;56(10):3319-25.

49. Laslett LL, Quinn S, Burgess JR, Parameswaran V, Winzenberg TM, Jones G, Ding C. Moderate vitamin D deficiency is associated with changes in knee and hip pain in older adults: a 5-year longitudinal study. Ann Rheum Dis. 2014;73(4):697-703.

50. Ledingham J, Dawson S, Preston B, Milligan G, Doherty M. Radiographic progression of hospital referred osteoarthritis of the hip. Ann Rheum Dis. 1993;52(4):263-7.

51. Lievense AM, Koes BW, Verhaar JAN, Bohnen AM, Bierma-Zeinstra SMA. Prognosis of hip pain in general practice: a prospective followup study. Arthritis Care Res. 2007;57(8):1368-74.

52. Maillefert JF, Gueguen A, Monreal M, Nguyen M, Berdah L, Lequesne M, Mazieres B, Vignon E, Dougados M. Sex differences in hip osteoarthritis: results of a longitudinal study in 508 patients. Ann Rheum Dis. 2003;62(10):931-4.

53. Mazieres B, Garnero P, Gueguen A, Abbal M, Berdah L, Lequesne M, Nguyen M, Salles JP, Vignon E, Dougados M. Molecular markers of cartilage breakdown and synovitis at baseline as predictors of structural progression of hip osteoarthritis. The ECHODIAH* cohort. Ann Rheum Dis. 2006;65(3):354-9.

54. Nelson AE, Golightly YM, Kraus VB, Stabler T, Renner JB, Helmick CG, Jordan JM. Serum transforming growth factor-beta 1 is not a robust biomarker of incident and progressive radiographic osteoarthritis at the hip and knee: the Johnston County Osteoarthritis Project. Osteoarthr Cartilage. 2010;18(6):825-9.

55. Perry GH, Smith MJ, Whiteside CG. Spontaneous recovery of the joint space in degenerative hip disease. Ann Rheum Dis. 1972;31(6):440-8.

56. Peters TJ, Sanders C, Dieppe P, Donovan J. Factors associated with change in pain and disability over time: a community-based prospective observational study of hip and knee osteoarthritis. Br J Gen Pract. 2005;55(512):205-11.

57. Pisters MF, Veenhof C, van Dijk GM, Heymans MW, Twisk JWR, Dekker J. The course of limitations in activities over 5 years in patients with knee and hip osteoarthritis with moderate functional limitations: risk factors for future functional decline. Osteoarthr Cartilage. 2012;20(6):503-10.

58. Pollard TCB, Batra RN, Judge A, Watkins B, McNally EG, Gill HS, Arden NK, Carr AJ. Genetic predisposition to the presence and 5-year clinical progression of hip osteoarthritis. Osteoarthr Cartilage. 2012;20(5):368-75.

59. Reijman M, Hazes JMW, Bierma-Zeinstra SMA, Koes BW, Christgau S, Christiansen C, Uitterlinden AG, Pols HAP. A new marker for osteoarthritis: cross-sectional and longitudinal approach. Arthritis Rheum. 2004;50(8):2471-8.

60. Reijman M, Hazes JMW, Pols H, Bernsen RMD, Koes BW, Bierma-Zeinstra SMA. Role of radiography in predicting progression of osteoarthritis of the hip: prospective cohort study. Br Med J. 2005;330(7501):1183-5.

61. Reijman M, Pols HAP, Bergink AP, Hazes JMW, Belo JN, Lievense AM, BiermaZeinstra SMA. Body mass index associated with onset and progression of osteoarthritis of the knee but not of the hip: the Rotterdam Study. Ann Rheum Dis. 2007;66(2):158-62.

62. Solignac M. Biological markers of osteoarthritis: data from the ECHODIAH cohort. Presse Med. 2004;33(9 Pt 2):S13-5.

63. Van Spil WE, Welsing PM, Bierma-Zeinstra SM, Bijlsma JW, Roorda LD, Cats HA, Lafeber FP. The ability of systemic biochemical markers to reflect presence, incidence, and progression of early-stage radiographic knee and hip osteoarthritis: data from CHECK. Osteoarthr Cartilage. 2015;23(8):1388-97.

64. Thompson NW, Corr AM, Geddis CJ, O'Brien S, Beverland DE. Rapidly progressive osteoarthrosis of the hip. HIP Int. 2004;14(4):217-22.

65. Tron AM, Conrozier T, Mathieu P, Vignon E. [Rate of joint space pinching in coxarthrosis] Vitesse de pincement de l'interligne articulaire dans la coxarthrose. Rev Rhum Ed Fr. 1994;61 (9 Pt 2):124S-30S.

66. Verkleij SPJ, Hoekstra T, Rozendaal RM, Waarsing JH, Koes BW, Luijsterburg PAJ, Bierma-Zeinstra SMA. Defining discriminative pain trajectories in hip osteoarthritis over a 2-year time period. Ann Rheum Dis. 2012;71(9):1517-23.

67. Vinciguerra C, Gueguen A, Revel M, Heuleu JN, Amor B, Dougados M. Predictors of the need for total hip replacement in patients with osteoarthritis of the hip. Rev Rhum Engl Ed. 1995;62(9):563-70.

\section{Publisher's Note}

Springer Nature remains neutral with regard to jurisdictional claims in published maps and institutional affiliations. 